\title{
Degree of Participation of Public Industrial Joint Stock Companies in Jordan in Activities Relating to Accounting Social Responsibility
}

\author{
Talal Souliman Jrairah ${ }^{1} \&$ Suleiman Hussien Al-Beshtawi ${ }^{2}$ \\ ${ }^{1}$ Associate professor, Accounting Dept., Jerash University, Jordan \\ ${ }^{2}$ Associate professor, Accounting Dept., AL-Israa University, Jordan \\ Correspondence: Suleiman Hussien Al-Beshtawi, Accounting Dept., AL-Israa University, Jordan. E-mail: \\ dr_sulieman@yahoo.com
}

Received: March 7, 2014

Accepted: May 11, 2014

Online Published: June 22, 2014

doi:10.5539/ijbm.v9n7p111

URL: http://dx.doi.org/10.5539/ijbm.v9n7p111

\begin{abstract}
The study aimed to identify the degree of participation on the part of the public industrial joint stock companies in Jordan in activities related to social responsibility accounting, and to get to know the bases of applying it. To achieve the purpose of the study, the two researchers designed a questionnaire and distributed it to the financial managers and accountants in the public industrial joint stock companies in Jordan included in Amman financial market during the month of May, 2013. The number of these managers and accountants was 81. Two questionnaires were assigned for each company, so the number of questionnaires which were used for analytical purposes was 98. (49 companies $\times 2$ ). The study showed that these companies did participate in the activities connected with the aspects of social responsibility accounting by using measures for applying them. However, these aspects of accounting were not given the same amount of attention. For example, priority was given to the quality of products and the protection of consumers; next came human resources and environment, while the local community came last. In addition, the act of disclosing social responsibility often takes the form of descriptive report within the framework of the annual financial reports.

The study suggested that a joint accounting model for social responsibility be designed where the elements of social activities are ordered according to their importance and disclosed. The study also stressed the need to develop a style for displaying financial lists that reveals bases and detailed information about social performance, and the social activities performed by industrial companies.
\end{abstract}

Keywords: social responsibility accounting, protecting a consumer, human resources, environment, local community

\section{Introduction}

The process of social responsibility accounting is considered to be an approach to the development of accounting. This development arises from the increasing size and capabilities of the companies which exert a wide range of financial economic and social influence. This has the effect of enhancing the social responsibility of these companies. These companies have been held responsible for the environmental pollution they cause, and for the comfort of their workers as well as for the protection of customers through improving the quality of products and services. Social responsibility accounting has come into being as a result of the importance of information associated with social responsibility of these companies to their future, and also as a result of more concern shown to it by the financial report users. All these has caused accounting to shift from its traditional role of the estimation of income, preparing and distributing reports and financial lists into a broad comprehensive role through defining the participation of companies in activities related to social responsibilities, which greatly contributes to the achievement of societal goals.

\subsection{The Study Problem}

The problem is centered around the degree of the participation of public industrial joint stock companies in Jordan in the social role towards 5 surroundings: environment, human resources, consumer and society as a whole. In the past two decades companies have paid much attention to their social role. So the aspects of the problem can be summed up and as follows: 
- To what extent have public industrial joint stock companies in Jordan contributed to the maintenance of environment as part of their social responsibility?

- To what extent have these companies been involved in the development of human resources within their social responsibility?

- To what extent have these companies participated in serving the local community within their social responsibility?

- To what extent have these companies contributed to the product quality and consumer protection within their social responsibility?

- To what extent are the bases of applying social responsibility accounting provided by these companies?

\subsection{Significance of Study}

The study derived its significance from the topic it tackled, which is related to social responsibility accounting, as industrial companies have to play a social role in addition to their economic role, considering the principle of cost and benefit.

The study also derived its importance from the fact that companies are no longer assessed on profitability alone. These companies no longer depend on establishing their reputation on their financial position alone, either. Rather there have appeared new concepts that assist in creating an environment that can cope with technological and administrative aspects. High among these is the concept of social responsibility.

Hence, this study, together with the results it will come up with, and the recommendations based on them will benefit all the parties concerned by encouraging industrial companies to enhance their participation in all aspects of social activities related to environment, human resources, as well as the protection of the local community and consumers.

\subsection{Aims of the Study}

The study aimed to identify the extent to which public industrial joint stock companies in Jordan are involved in activities connected with social responsibility accounting, and the possibility of applying them in these companies. These aims can be realized through:

- Identifying the amount of contribution of these companies to environment maintenance.

- Identifying the extent to which these companies can participate in developing human resources.

- Identifying the extent to which these companies participate in serving the local community.

- Identifying the extent to which these companies can improve product quality and protect a consumer.

- Identifying the extent to which these principles of applying social responsibility accounting in public industrial stock companies in Jordan are available.

\section{The Article Framework for Social Responsibility Accounting and Previous Studies}

The concept of social responsibility is counted to be a concept with deep roots in history dating back to long centuries. The idea of social responsibility is not a new concept in the 20th century. Rather, it dates back to the sixties of this century when the concept of social responsibility began to have broader dimensions. It was no longer confined to voluntary activities or dimensions. Rather, it took the form of programmes, plans and strategies (Asongu, 2007).

The concept of social responsibility has become more common and more important, and the term social responsibility accounting has become a modern term that is used in accounting thought. (Scheldon) referred to the responsibility of an organization as a social responsibility in the first place, and that in order for any organization to survive, it has to be fully committed to its social responsibilities in all respects (Jarbou, 2007).

Therefore, social responsibility accounting is regarded as a mirror that reflects the degree of commitment of enterprises to their social responsibilities whether this commitment is voluntary or legal (Laufer, 2003).

(Asongu, 2007) defined social responsibility as the relationship between the organization and the community it works within. It emphasizes the commitments that an organization has to fulfill so that it can be considered an example of good citizenship. The World Bank, however, defined social responsibility of the private sector institutions as: being committed to the contribution to sustained development through the cooperation of their employees with the local community as a whole, to improve the living standard of people in a way that serves both business and development at the same time (World Bank, 2005).

The European Legation defined social responsibility as a concept in which an organization combines social and environmental interests in its business transactions and dealings on a voluntary basis. (Abdul-Mutaal and Rifa'I, 2007) As for (Seider), he defines social responsibility as one o the elements of accounting in its broad sense; that 
is, it is an art or science which aims to measure and explain the activities and phenomena which originally have a socio-economic nature (Al-Fadl et al., 2002).

The stronger motives for the organizational social responsibility lie in promoting self-interest, social investment, transparency and trust, and high expectations of the public from companies (The association of Banks in Jordan, 2011).

The European legation determined two major dimensions in companies, namely; the internal and external dimensions. The internal dimension is associated with the practices within the company which require modification so as to include social responsibility practices. This dimension includes the management of human resources, smoothness of work and hygienic measures. The health of an employee and safety standards have a direct effect on productivity. The internal dimension also includes the element of managing environmental effects, which necessitates less consumption, less waste of resources, and pollution caused by negative practices of the company, as well as the necessity of environmental investment.

The external dimension is associated with the company's external environment, including local communities or business companies (importers, customers, and sometimes competitors). This dimension also concerns with keeping human rights, for these companies contribute to local communities via employments, training, pay rise, advantages, and taxes.

The development in the accounting element has led to more interest in the social responsibility of the companies in modern times. Organizations are held accountable for the environmental pollution they produce, in addition to their responsibility for the workers' well-being. They are also accountable for providing protection to their customers through the improvement of the quality of services rendered to them. So there have been more and more studies that aim to state social performance, standard of organizations, and the social impact of this standard on preparing the reports and financial lists of social nature. Despite the fact that social responsibility accounting has become a reality that can never be ignored by a company, researchers are not yet agreed on a definite, clear definition of it.

(Al-Shirazy, 1990) defined social responsibility as a group of activities intended to measure and analyze the social performance of a certain unit of accounting, and communicate this information to the specialist parties and groups who are in need of it. This will help them in taking decisions and assessing the social role of the organization. (Al Hussein, 2003) indicates that the aims of social responsibility accounting are exemplified in measuring the net social contribution of an organization, assessing the social role of an organization, and disclosing the activities carried out by an organization. Khalaf, (2009) notes that the most important advantages of social responsibility accounting are: to enable an organization to estimate the production cost more accurately; to determine the production cost appropriately; and to develop the company workers' awareness of health affairs and vocational safety.

The concept of social responsibility accounting is viewed via three angles: first, looking at social accounting as an extension or complement to the areas of financial accounting. This requires that financial lists should include thorough data or information about social performance, and essential data about the economic performance of an organization. Second, looking at social responsibility accounting with broader and more comprehensive perspective as a comprehensive intellectual framework of accounting in general, rather than just a branch of financial accounting; finally, viewing social responsibility accounting as a unique concept which has its own particularities within the general framework of accounting, as in the case of financial administrative and cost accounting. The system of social responsibility accounting also has its own characteristics that make it similar to other systems of accounting (Matar \& Suwaiti, 2008).

As for the measurement of social responsibility which is represented by identifying exchange processes, or activities with social implications, is considered the most difficult problem affecting the current intellectual framework of accounting. The main reason for this difficulty lie in the difficulty of measuring social activities, for some of these activities have no definite financial value. This has the effect of ignoring them or just disclosing them through some observations about financial lists. This case is similar to the procedures taken by an economic unit to protect a consumer from misusing the products, or monitoring pollution. Hence, the difficulty of measuring the effect of social exchanges impedes the process of measuring them (Khalaf, 2009). It is noticed that writers are not agreed on accounting standards that can be relied on when disclosing the effects of the different items of social responsibility related to the economic unit. Most attempts aimed to provide a sound basis for providing the information and data connected with these activities. The American Accountants Association found that these standards can be represented by:

Primary: represented by suitability, being unbiased and understandability. 
Secondary: represented by proper timing, achievability, comparability and brevity.

Additional considerations: represented by the significance of data, centralization, caution, acceptance, right to objection, consistency, quantity measure, cash measure, permanent test and possibility of assessment.

Among the styles which are suggested for disclosing social activities (Al sharairi \& Al mornani, 2006) are:

- The style of enlisting social activities in a report which is separate from financial reports. This report includes the sums of money spent on each social activity, and displayed with the financial lists simultaneously, but it does not include the benefits behind these activities.

- The style of enlisting social activities within financial lists without resorting to cost analysis and activity benefits. The report in this case takes a descriptive form devoid of financial values. The social activities in this sort of style are categorized into four groups: employees or human resources, environment, community, and consumers.

- The style of displaying social activities within the financial lists, showing all the sums of money spent on each activity. This style depends on disclosing quantity information, activities achieved, and the measurements of benefits gained from these activities as compared to the sums of money spent.

- The style of displaying social activities separate from financial lists, here the list includes costs and social benefits. This list is called the social impact list in which benefits, costs, net deficit, or the social surplus gained for the community.

we can be disclosed through an investigation into the accounting thought and the practical application in relation to the process of disclosing this information about social activities which economic enterprises follows, it turns out that there are two ways :

Separation: enlisting information linked with the social responsibility accounting in lists separate from financial accounting.

Combining: This way is based on combining the information about social responsibility accounting with the traditional information of financial accounting within the financial lists. (Al Qadi \& Hamdan, 2001)

\subsection{Previous Studies}

The study of (Ziyoud, 2013): This study aimed to find out the extent of Jordan Banks commitment to their social responsibility towards the external and internal surroundings of their workers. The study hypothesis was applied to 15 banks between 2008 and 2010. The study concluded that banks take a responsibility for the local community as part o their plans and policies aiming at achieving sustained development as for as the internal dimension is concerned, it turned out that the sum of money spent on workers were insufficient and that the workers were not trained and developed as should be.

The study of (Al Farah \& Al Hindawi, 2011): The study aimed to find out the degree of the disclosure of the social responsibility elements in the annual company reports of the Jordan industrial companies subsumed under Amman Stock Exchange, for the years 2007 and 2008. The study also aimed to identify the effect of the assets and sales 'size on the degree of accentuating the social responsibility elements. The study consisted of 72 industrial companies. It was found out that there was a variation in terms of the level of the disclosure of social responsibility elements between companies. The highest percentage of disclosure went to the environment preservation. The findings of the size of assets and sales had no statistically significant impact on the level of social disclosure.

The study of (Mishra \& Suar, 2010): This study aimed to check whether the companies social responsibility has an impact on financial and non- financial performance. So a questionnaire was distributed to 150 consecutive principals at the Indian industrial companies. As for as the information concerning financial performance, this was obtained from secondary resources. Social responsibility was assessed on the basis that people concerned with social responsibility consist of 6 groups: employees, agents, investors, community, environment and suppliers. The results showed that the social responsibility of the companies subsumed under the financial market were better than companies outside the markets, the thing which positively reflects on their financial performance. Therefore, companies that disclose their social responsibility enjoy better financial performance.

The study of (Rahahleh \& Sharairi, 2008): The study emphasized the degree to which industrial estates apply and understand the concept of social responsibility accounting to achieve this purpose; the study employed the descriptive approach as well as secondary information from specialized studies. The study population consisted of 107 companies. Questionnaire was distributed to these companies. The study showed that these companies were not fully aware of the concept of social responsibility except for certain phenomena, and that the concept 
was not fully applied except in certain aspects. The study recommended that social performance at industrial companies has to be considered and given weight the study also recommended holding training courses and workshops, for workers about the social responsibility accounting. Attention has to be given to the measurement of social costs benefits and disclosure.

The study of (Jarbou, 2007): This research aimed to find out whether there are business organizations concerned with social responsibility in Gaza strip. To achieve the practical aspects of the study, a questionnaire based on the previous studies and theoretical framework was designed. The questionnaire was distributed to financial managers and company accountants. The results of the study showed that social responsibility accounting has not been given enough attention by vocational societies for accounting and reviewing. The results also showed that the general framework of social responsibility is not well-defined and its dimensions have not been decisively agreed on to date. The study also showed that social responsibility accounting for these enterprises is an activity that can be defined in terms of its types, areas, aims and variations, and finally this activity can be measured and its results can be objectively disclosed.

The study of (Smith, 2007): this study aimed to discuss Maurice Stans writings and observations which he had gathered in his capacity as an expert in accountancy and the principal of the American Institute for Accountancy. The study concluded that the disclosure of the activities of social accounting in financial reports will lead to more clarity as to the nature of company work, in addition to the reliability of these reports.

Study of (Sharairi \& Mamani, 2006): This study aimed to find out the extent of Jordan Industrial companies 'participation in social activities and environment protection through field researches, to investigate the possibility of playing the required role towards community by these companies, to disclose the role of the statement of social activities the company provides through accountancy, and to examine the ability of joint stock companies to render services to the local community in terms of unemployment, fighting poverty and health care. The study concluded that industrial companies in Jordan care for environment, fight poverty and unemployment, render medical and industrial services to the local community. In addition to this, these companies disclose these social services at different proportions from one activity to another through the accountancy statements.

\subsection{Characteristics of This Study}

This study differs from previous studies in that it focuses on:

- The contribution of the public industrial stock companies in Jordan to the activities associated with social responsibility accounting, and the relative importance of these areas.

- The degree of these companies' commitment to the disclosure of social responsibility activities in their financial lists.

- The basis of applying accounting to social responsibility through a system of accounting which can measure social performance and through the government laws, rules and legislation related to social responsibility and the extent of the companies' commitment to applying them.

\section{Study Hypothesis}

According to the theoretical framework and previous studies, and in order to answer the questions raised in the study problem, the following hypotheses were formulated:

- The First Hypothesis: Public industrial stock companies in Jordan do not pay attention to environment as part of their social responsibilities.

- The Second Hypothesis: Public industrial stock companies in Jordan do not contribute to the development of human resources within their social responsibilities.

- The Third Hypothesis: Public industrial stock companies in Jordan do not contribute to serving the local community within their social responsibilities.

- The Fourth Hypothesis: Public industrial stock companies in Jordan do not participate in improving product quality and consumer protection as part of their social responsibilities.

- The Fifth Hypothesis: Public industrial stock companies in Jordan lack.

\section{The Study Approach}

\subsection{Population and Sample of the Study}

The population of the study consists of the public industrial stock companies in Jordan, numbering 81, which were subsumed under Amman Market for securities. The sample size was 57 companies after excluding the 
companies going into liquidation and companies which ignored the questionnaire. The questionnaire was distributed to the financial managers and accountants, 2 questionnaires to each company. The number of the questionnaires which were valid and accredited was $98(49$ companies $\times 2)$, a percentage of $(60.49 \%)$ of the study population.

\subsection{Data Resources}

This study was based on two types of data: secondary data, represented by library contents, such as researches, studies published in periodicals, scientific journals and books relevant to the study subject. The other data was directly gathered Via field visits to Jordan industrial companies where two questionnaires designed by the researchers were distributed and completed.

\subsection{Data Gathering Instrument}

An instrument for gathering data (a questionnaire) based on published literature about social responsibility accounting: this questionnaire was offered to some teaching staff members in the accounting department to be assessed and developed, and a number of financial managers and accountants in some companies were also consulted to achieve the highest degree of accuracy and objectivity so that the questionnaire results could be acceptable and reliable.

Table 1 states the questionnaire sections and the questions measuring each study variable.

Table 1 . The questionnaire sections and study variables

\begin{tabular}{clc}
\hline Section & \multicolumn{1}{c}{ Variable } & Questions measuring-variable \\
\hline One & - Qualification & 1 \\
& - Specialization & 2 \\
& - Job Description & 3 \\
& - Work Experiences In The Present Job & 4 \\
\hline Two & Protecting Environment & $1-8$ \\
& Developing Human Resources & $9-18$ \\
& Serving Local Community & $19-24$ \\
& Protecting Customers & $25-31$ \\
& Application Bases & $32-41$ \\
\hline
\end{tabular}

\subsection{Statistical Analysis Styles}

In the study, two styles of statistics were adopted: analytical statistics and descriptive statistics. These were intended to point out the extent to which public industrial stock companies in Jordan participate in activities related to areas of social responsibility accounting. Statistical package for the social sciences (SPSS) was used to extract the result associated with the statistical style being used in the study, namely:

Description statistics: in which the percentage of frequencies of comparison between the dimensions measuring the study variables were employed together with the mean.

Compare Means: The one sample T-test aiming to disclose a significant difference of the mean of the community, from which the sample was drawn, from a fixed value, limited to the value (3) in the study.

\subsection{Reliability of the Study Instrument}

To test the instrument reliability, Chronbach's alpha coefficient of internal consistency between the questionnaire items was estimated, in addition, split-half method of estimating reliability according to Spearman-Brown formula was used as well the value of Cronbach's coefficient between all the questionnaire items amounted to (0.8358), and the value reliability according to spearman-brawn formula was $(0.7336)$. These values indicate the reliability of the study instrument. Table (2) shows the reliability coefficients of the study variables. 
Table 2. Reliability coefficients of the study variables

\begin{tabular}{clcc}
\hline Items & Variables & Cronbach's Alpha & Spearman-Brown \\
\hline $1-8$ & Environment protection & 0.8420 & 0.7424 \\
$9-18$ & Human resources development & 0.8071 & 0.8001 \\
$19-24$ & Local community services & 0.7249 & 0.6989 \\
$25-31$ & Consumer protection & 0.7750 & 0.7220 \\
$32-41$ & Bases of application & 0.8258 & 0.7106 \\
$1-41$ & Reliability general rates & 0.838 & 0.7336 \\
\hline
\end{tabular}

To test the measure the study questionnaire, the degree of approval was divided into three levels: high, medium, low according to the measure: $(5-1) / 3=1.33$ that is the class length, so the classes were divided as follows:

\begin{tabular}{cc}
\hline Degree of Approved & Mean \\
\hline High & $3.68-5.00$ \\
Medium & $2.34-3.67$ \\
Low & $1.00-2.33$ \\
\hline
\end{tabular}

\subsection{Properties of the Study Sample}

Table 3. Shows the properties of the study sample respondents

\begin{tabular}{|c|c|c|c|c|}
\hline No. & Variable & Responses & Number & Percentage \\
\hline \multirow{5}{*}{1.} & \multirow{5}{*}{ Qualification } & Diploma\& community college and below & 29 & $29.59 \%$ \\
\hline & & Bachelors' degree & 54 & $55.10 \%$ \\
\hline & & Master's degree & 12 & $12.24 \%$ \\
\hline & & Doctor of philosophy & 3 & $3.06 \%$ \\
\hline & & Total & 98 & $100 \%$ \\
\hline \multirow{6}{*}{2.} & \multirow{6}{*}{ Specialization } & Accounting & 58 & $59.18 \%$ \\
\hline & & Business administration & 21 & $21.43 \%$ \\
\hline & & Financial \& banking sciences & 13 & $13.27 \%$ \\
\hline & & Economics & 2 & $2.04 \%$ \\
\hline & & Another specialization & 4 & $4.08 \%$ \\
\hline & & Total & 98 & $100 \%$ \\
\hline \multirow{3}{*}{3} & \multirow{3}{*}{ Job description } & Financial manager & 49 & $50 \%$ \\
\hline & & Accountant & 49 & $50 \%$ \\
\hline & & Total & 98 & $100 \%$ \\
\hline \multirow{6}{*}{4} & \multirow{6}{*}{ Work experience } & Less than 3 years & 8 & $8.16 \%$ \\
\hline & & From 3-less than 6 & 26 & $26.53 \%$ \\
\hline & & From 6-less than 9 & 37 & $37.76 \%$ \\
\hline & & From 9-less than 12 & 16 & $16.33 \%$ \\
\hline & & 12 years more & 11 & $11.22 \%$ \\
\hline & & Total & 98 & $100 \%$ \\
\hline
\end{tabular}

Table 3, as we see, shows that $(55.10 \%)$ of the respondents are BA holders, so most of the sample members are well - qualified. The responses associated with specialization were centered around accounting $(59.18 \%)$. This is a positive indication of the member's ability to understand the study subject.

The reliability of the result is enhanced by the fact that the respondents enjoy high experience in their present job, the percentage of respondents who have less than 6 years is $(37.76 \%+16.33 \%+11.22 \%)=65.31 \%$.

\subsection{Testing the Hypothesis}

\subsubsection{The First Hypothesis}

Public industrial stock companies in Jordan do not participate in protecting the environment as part of their social responsibility. 
This hypothesis was tested through the first 8 questions of the questionnaire (1-8). Table (4) states the result of the statistical analysis associated with the contribution of public industrial stock companies in Jordan to the protection of environment.

Table 4. Results of the study sample response about the extent to which public industrial stock companies in Jordan contribute to the protection of environment

\begin{tabular}{|c|c|c|c|c|c|}
\hline No. & Item & Mean & $\begin{array}{l}\text { Standard } \\
\text { deviation }\end{array}$ & Order & $\begin{array}{l}\text { Approval } \\
\text { degree }\end{array}$ \\
\hline 1 & $\begin{array}{l}\text { Companies participate in environment protection programmers } \\
\text { and pollution reduction }\end{array}$ & 3.96 & 1.28 & 1 & High \\
\hline 2 & $\begin{array}{l}\text { Companies set up divisions or offices responsible for reducing } \\
\text { environmental pollution }\end{array}$ & 1.98 & 1.10 & 8 & Low \\
\hline 3 & Companies use machines which cause less pollution & 3.12 & 1.23 & 5 & Medium \\
\hline 4 & Companies use more economical machines for environment & 3.06 & 1.18 & 6 & Medium \\
\hline 5 & $\begin{array}{l}\text { Companies conduct researches and studies to reduce industrial } \\
\text { pollution }\end{array}$ & 2.31 & 1.07 & 7 & Low \\
\hline 6 & $\begin{array}{l}\text { Companies recycle production outputs and waste and treat } \\
\text { them to reduce environment damage }\end{array}$ & 3.86 & 1.06 & 3 & High \\
\hline 7 & Companies beautify and plant trees in the surrounding areas & 3.88 & 1.00 & 2 & High \\
\hline 8 & $\begin{array}{l}\text { Companies provide guidance, and help reduce natural } \\
\text { resources consumption }\end{array}$ & 3.71 & 0.85 & 4 & High \\
\hline In total & Items related to the protection of environment & 3.24 & 0.55 & - & medium \\
\hline
\end{tabular}

Table 4 shows that the sample members responses (1), (7), (6) had high means $(3.96,3.88,3.86)$ (high approval) and with the standard deviation $(1.28,1.00,1.06)$ This indicates that the sample companies participate in customer protection programmes, plant and beautify the surrounding areas, and recycle and treat production waste.

Items $(2,5)$ had low means $(1.98,2.31)$, respectively (low approval) and with the standard deviation $(1.10,1.07)$ and this means that the sample companies have no divisions or officers which are responsible in an actual and independent way for environmental pollution. It also means that there are serious researches addressing environmental pollution. The other questionnaire items had an approval degree ranging from medium to high.

In general, the data analysis results related to this hypothesis show that the contribution of public industrial stock companies in Jordan to environmental protection was medium the means of the whole question was ( 3.24 ) and the standard deviation was (0.55), which indicates clear agreement and lack of variation between the respondents' answers.

In order to verify the statistical significance of the results above and test the first hypothesis, the one-sample T-test was employed.

Table 5. Illustrates the results of the first hypothesis

\begin{tabular}{cccccc}
\hline Variable & T tabulated & T calculated & $\begin{array}{c}\text { Statistical } \\
\text { significance }\end{array}$ & $\begin{array}{c}\text { Degree of } \\
\text { freedom }\end{array}$ & Hypothesis test result \\
\hline $\begin{array}{c}\text { Environment } \\
\text { protection }\end{array}$ & 1.660 & 5.511 & 0.000 & 97 & Rejection \\
\hline
\end{tabular}

Note. *Statistically significant differences at level $(0.05) ; *$ Significance level does not exactly equal o, but approximately 0 , but the computer does not display the number which is less than zero after the third place.

The result tests in Table 5 indicate that the $\mathrm{T}$ calculated value (5.511) is higher than the T tabulated value (1.660) and that its significant level is $(0.000)$ and since the decision base indicates the acceptance of the null hypothesis if the value of $\mathrm{T}$ accepted is less than that of $\mathrm{T}$ tabulated and the Rejection of the null hypothesis if the value of $\mathrm{T}$ accepted is greater than that of the T tabulated, the null hypothesis will be rejected and the alternative one is accepted. The alternative hypothesis states that public industrial stock companies in Jordan do contribute to environment protection. 


\subsubsection{The Second Hypothesis}

Public industrial stock companies in Jordan do not contribute to their human resources as part of their social responsibility.

This hypothesis was tested depending on the question (9-18) of the questionnaire; Table (6) illustrates the results of the statistical analysis of the questions associated with the development of human resources.

Table 6. Results of the sample study responses concerning the extent to which public industrial stock companies in Jordan contribute to human resources

\begin{tabular}{|c|c|c|c|c|c|}
\hline No. & Items & Mean & $\begin{array}{l}\text { Standard } \\
\text { deviation } \\
\end{array}$ & Order & $\begin{array}{c}\text { Approval } \\
\text { degree }\end{array}$ \\
\hline 9 & $\begin{array}{l}\text { The companies provide appropriate working conditions and } \\
\text { leisure time to their workers }\end{array}$ & 3.98 & 0.99 & 4 & High \\
\hline 10 & $\begin{array}{l}\text { The companies adopt fair bases of salaries, promotion and } \\
\text { incentives according to the workers abilities and contribution }\end{array}$ & 4.01 & 0.90 & 3 & High \\
\hline 11 & The companies contribute to the education of workers' children & 2.32 & 0.94 & 7 & Low \\
\hline 12 & $\begin{array}{l}\text { The companies organize training courses to promote workers } \\
\text { skills and improve their job performance }\end{array}$ & 3.91 & 0.87 & 5 & High \\
\hline 13 & The companies provide transportation for workers & 4.48 & 0.63 & 1 & High \\
\hline 14 & The companies provide accommodation for workers & 2.28 & 1.69 & 10 & Low \\
\hline 15 & The companies help provide health insurance system for workers & 4.41 & 0.70 & 2 & High \\
\hline 16 & $\begin{array}{l}\text { The companies provide a system of insurance and pension for } \\
\text { workers }\end{array}$ & 2.30 & 0.96 & 8 & Low \\
\hline 17 & The companies form sports team from their workers & 2.30 & 0.96 & 8 & Low \\
\hline 18 & $\begin{array}{l}\text { The companies involve their workers in social and recreational } \\
\text { programmers outside working hours }\end{array}$ & 2.29 & 1.16 & 9 & Low \\
\hline In total & Items associated with human resources development & $\mathbf{3 . 3 7}$ & 0.05 & & medium \\
\hline
\end{tabular}

As we can see Table 6 shows that the approval level according to the sample members responses to items (13.15) was high, with the means $(4.48,4.4)$ and standard deviation $(0.63,0.70)$, respectively. This indicates that the sample companies give considerable attention to health insurance and transport.

Item (10) has a mean as high as (4.01) and a standard deviation of (0.90), which means that stock companies adopt fair systems of salaries, promotion and incentives. Item (9) has a mean of (3.98 ) ( high approval ) and a standard deviation of (0.99), which emphasizes that providing suitable working conditions, costly though, enhances the efficiency of productivity and increases the company income as a result. In contrast, items $(14,18$, $17,11)$ have low means $(2.28,2.29,2.30,2.32)$ respectively with a low level of approval. This is due to the fact that some companies believe that securing accommodation, organizing recreational activities, forming sports teams, and providing education for workers' children do not benefit the company and are just extra expenses. These activities, in fact, enhance workers pride and trust in the company, and considered to be in the meanwhile an indirect propaganda to the company. The other items, however, were close to one another and with a higher approval level.

To verify the statistical significance of the result above, and to test the second hypothesis, the One-sample T-test was used. Table 7 illustrates the results of the second of hypothesis test.

Table 7. Result of the second hypothesis T-test

\begin{tabular}{cccccc}
\hline Variable & T tabulated & T calculated & $\begin{array}{c}\text { Statistical } \\
\text { significance }\end{array}$ & $\begin{array}{c}\text { Degree of } \\
\text { freedom }\end{array}$ & $\begin{array}{c}\text { Hypothesis test } \\
\text { result }\end{array}$ \\
\hline Human resources & 1.660 & 12.227 & 0.000 & 97 & rejection \\
\hline
\end{tabular}

$\mathrm{T}-$ Test results (Table 7) show that the value of $\mathrm{T}$ calculated (12.227) is greater than that of $\mathrm{T}$ tabulated (1.660) and its statistical significance (0.000); and accordingly, the null hypothesis is rejected and the alternative one is accepted. The latter result states that public industrial stock companies in Jordan do contribute to human resources development. 


\subsubsection{The Third Hypothesis}

Public industrial stock companies in Jordan do not participate in local community services as part of their social responsibilities.

This hypothesis was tested depending on the question (19-24) of the questionnaire. Table 8 illustrates the statistical analysis of the questions associated with local community service.

Table 8. Results of the study sample responses around the extent to which public industrial stock companies in Jordan periapt in local community service

\begin{tabular}{|c|c|c|c|c|c|}
\hline No. & Item & Mean & $\begin{array}{c}\text { Standard } \\
\text { Deviations }\end{array}$ & Order & $\begin{array}{l}\text { Approval } \\
\text { level }\end{array}$ \\
\hline 19 & $\begin{array}{l}\text { The companies support educational institutions, health facilities, } \\
\text { and sport clubs }\end{array}$ & 3.71 & 1.49 & 2 & High \\
\hline 20 & The companies donate money to charities and cooperative societies & 3.69 & 0.74 & 3 & High \\
\hline 21 & The companies carry out projects in poorer areas & 2.26 & 1.50 & 6 & Low \\
\hline 22 & $\begin{array}{l}\text { The companies help in training university and college students } \\
\text { during and after their study }\end{array}$ & 3.81 & 0.92 & 1 & High \\
\hline 23 & the companies employ workers with special requirements & 3.06 & 1.00 & 4 & Medium \\
\hline 24 & $\begin{array}{l}\text { The companies set plans and programs to reduce poverty. } \\
\text { unemployment and illiteracy }\end{array}$ & 2.28 & 1.01 & 5 & Low \\
\hline In total & The items associated with local community service & 3.14 & 0.61 & - & medium \\
\hline
\end{tabular}

Table 8 , as you can see shows that the sample members' responses to items $(22,19,20)$ had greater means $(3.81$, $3.71,3.69)$ and receptivity. These items are linked with the companies' acceptance of training university and college students, supporting educational institutions health facilities, 16 sports clubs, and donation to charities. This means that companies accept taking responsibility for developing their relationship with the local community. In contrast, items $(21,24)$ relating to the establishment of projects in poor areas and setting plans and programmers to reduce poverty, unemployment and illiteracy won low level of approval as their means indicate $(2.26,2.28)$,respectively with the standard deviations $(1.50,1.01)$

To verify the statistical significance of the results above and to test the third hypothesis, the one-sample. T-Test was employed. Table 9 illustrates the results of the third hypothesis.

Table 9. Results of the third hypothesis based $\mathrm{m}$ T-test

\begin{tabular}{cccccc}
\hline Variable & T tabulated & T calculated & $\begin{array}{c}\text { Statistical } \\
\text { significance }\end{array}$ & $\begin{array}{c}\text { Degree of } \\
\text { freedom }\end{array}$ & $\begin{array}{c}\text { Hypothesis test } \\
\text { result }\end{array}$ \\
\hline Local community & 1.660 & 4.579 & 0.000 & 97 & refusal \\
\hline
\end{tabular}

The result of the test in Table 9 show that the value of the $\mathrm{T}$ calculated (4.579) is higher than that of $\mathrm{T}$ tabulated (1.660) whose statistical significance is $(0.000)$. Therefore the null hypothesis is rejected and the alternative one is accepted. The latter hypothesis states that public industrial joint stock companies in Jordan contributed to the service of local community.

\subsubsection{The Fourth Hypothesis}

Public industrial stock companies in Jordan do not help in the improvement of product quality and consumer protection as part of their social responsibilities.

This hypothesis was tested depending on the questions (from 25 to 31) of the questionnaire. Table (10) illustrates the results of the statistical analysis of the questions linked with product quality improvement and consumer protection. 
Table 10. Results of study sample responses concerning the extent to which public industrial stock companies in Jordan contribute to product quality improvement and consumer protection

\begin{tabular}{|c|c|c|c|c|c|}
\hline No. & Item & Mean & $\begin{array}{l}\text { Standard } \\
\text { deviation }\end{array}$ & Order & $\begin{array}{c}\text { Approval } \\
\text { level }\end{array}$ \\
\hline 25 & The companies produce high quality products & 3.81 & 1.21 & 3 & High \\
\hline 26 & $\begin{array}{l}\text { The products have clear directions showing their contents, their } \\
\text { way of use, and their validity }\end{array}$ & 3.74 & 1.49 & 5 & High \\
\hline 27 & $\begin{array}{l}\text { The companies respond to the customers' complaints and } \\
\text { suggestions }\end{array}$ & 3.68 & 0.98 & 6 & High \\
\hline 28 & The companies stick to the consumer protection legislation & 3.76 & 1.30 & 4 & High \\
\hline 29 & $\begin{array}{l}\text { The companies produce a variety of goods and services in } \\
\text { response to customers' needs }\end{array}$ & 3.68 & 1.00 & 7 & High \\
\hline 30 & $\begin{array}{l}\text { Te companies lunch advertising campaigns to introduce the } \\
\text { properties of a product and how it is used }\end{array}$ & 4.11 & 0.84 & 1 & High \\
\hline 31 & $\begin{array}{l}\text { The companies do marketing research to determine customers' } \\
\text { needs }\end{array}$ & 4.06 & 0.82 & 2 & high \\
\hline In total & $\begin{array}{l}\text { The items related to product quality improvement and } \\
\text { customer protection }\end{array}$ & 3.83 & 0.64 & - & high \\
\hline
\end{tabular}

Table 10, as we see, shows that : the items connected with product quality improvement and consumer protection all have great means, and this means that there is almost a general agreement among the sample companies that they are responsible for everything and that these companies exert their responsible role towards customers. This, of course, indicate that companies view customers as the market on which their success or failure depends. Hence, consumer satisfaction is considered as the companies' chief aims.

In order to verify the statistical significance of the results above and to test the fourth hypothesis, the one-sample t-test was employed. Table 11 illustrates the results of the fourth hypothesis.

Table 11. Results of the fourth hypothesis T-test

\begin{tabular}{cccccc}
\hline Variable & T Tabulated & T Calculated & $\begin{array}{c}\text { Statistical } \\
\text { Significance }\end{array}$ & $\begin{array}{c}\text { Degree Of } \\
\text { Freedom }\end{array}$ & $\begin{array}{c}\text { Hypothesis Test } \\
\text { Result }\end{array}$ \\
\hline $\begin{array}{c}\text { Consumer } \\
\text { Protection }\end{array}$ & 1.660 & 12.971 & 0.000 & 97 & Rejection \\
\hline
\end{tabular}

The result of the test Table 11 show that the value of $\mathrm{T}$ calculated (12.971) is greater than that of $\mathrm{T}$ tabulated (1.660) whose statistical significance is $(0.000)$ and accordingly, the null hypothesis is rejected. The latter hypothesis states that public industrial stock companies in Jordan contribute to product quality improvement and customer protection.

\subsubsection{The Fifth Hypothesis}

Public industrial stock companions in Jordan do not have bases for applying social responsibility accounting. This hypothesis was tested through the questions (from 32 to 41) of the questionnaire. Table 12 illustrates the statistical analysis results of the questions related to the degree of the availability of applying bases for social responsibility accounting in public industrial stock companies in Jordan.

Table 12. Results of the study sample responses about the availability degree of applying bases for social responsibility accounting in public industrial stock companies in Jordan

\begin{tabular}{clcccc}
\hline No. & \multicolumn{1}{c}{ Item } & Mean & $\begin{array}{c}\text { Standard } \\
\text { deviation }\end{array}$ & Order & $\begin{array}{c}\text { Approval } \\
\text { level }\end{array}$ \\
\hline 32 & $\begin{array}{l}\text { The companies disclose the costs and social returns of their activity } \\
\text { The companies are fully aware of social responsibility in its broad } \\
33\end{array}$ & 2.31 & 1.06 & 6 & Low \\
& $\begin{array}{l}\text { sense } \\
\text { The difficulty in measuring costs and social benefits makes it difficult } \\
\text { for companies to apply }\end{array}$ & 3.04 & 0.85 & 3 & High \\
\hline
\end{tabular}




\begin{tabular}{|c|c|c|c|c|c|}
\hline 35 & $\begin{array}{l}\text { The accounting system applied by the companies is able to measure } \\
\text { social performance }\end{array}$ & 2.25 & 1.33 & 10 & Low \\
\hline 36 & $\begin{array}{l}\text { The companies disclose social responsibility data within their financial } \\
\text { lists }\end{array}$ & 2.27 & 1.34 & 8 & Low \\
\hline 37 & $\begin{array}{l}\text { The companies disclose a description of social responsibility data in the } \\
\text { appendices accompanied with published financial lists }\end{array}$ & 1.17 & 0.53 & 2 & High \\
\hline 38 & $\begin{array}{l}\text { The commitment of companies to laws, regulations and government } \\
\text { legislation is considered the only way to guarantee the application of } \\
\text { social responsibility accounting }\end{array}$ & 4.42 & 0.72 & 1 & High \\
\hline 39 & $\begin{array}{l}\text { There is a uniform model for disclosing social activities accounting } \\
\text { applied by all companies }\end{array}$ & 2.32 & 1.06 & 5 & Low \\
\hline 40 & $\begin{array}{l}\text { The best way of disclosing social activity accounting is giving freedom } \\
\text { to a company to chose the optimum way of disclosure }\end{array}$ & 2.26 & 1.12 & 9 & Low \\
\hline 41 & $\begin{array}{l}\text { The financial returns expected from the company's disclosure of its } \\
\text { social activates are higher than the cost of disclosing them }\end{array}$ & 2.30 & 1.06 & 7 & low \\
\hline In total & The items relating to the availability degree of applying bases & 3.02 & 0.52 & - & medium \\
\hline
\end{tabular}

Table 12, as we see, shows that the sample members responses to item (38) had the greatest mean (4.42) (high approval level), and with a standard deviation (0.72). This means that the application of social responsibility accounting requires legal legislation, and this necessitates updating, laws, rules and legislation concerning the rendering and activating social services on the part of the companies to be able to provide the social services and disclosing them in accounting. This, of course, enhances companies' interest in social performance, and measuring it in terms of quality and quantity. The sample members ' response to item (37) showed a mean of (4.17) (high approval level) and a standard deviation of (0.53) and this indicates that the disclosure of social responsibility accounting often takes the form of a descriptive report within the annual financial reports with the help of some simple figures and proportions.

The sample members ' responses to items $(35,40,36,41,32,39)$ showed low means $(2.25,2.26,2.27,2.30,2.31$, 2.32), respectively. This indicates that:

- The outputs of current accounting systems adopted by companies are still incapable of disclosing the costs and benefits of social responsibility.

- The expected financial returns due to the disclosure of industrial companies of their social activities are often less than the costs being disclosed. The reason according to industrial companies is that social responsibility is not profitable. Rather, it is a moral commitment, and social activities often have no financial returns.

- Difficulty in measuring financial data related to costs and social benefits. There are real accounting problems which can hardly be measured. The result is that the integration of social information with financial data becomes a more complicated process.

- There is a real commitment to a uniform accounting model, which stresses the need of setting a uniform social accounting model to be applied in all companies, which is easy to understand and apply with acceptable cost.

In order to verify the statistical significance of the results above, and test the fifth hypothesis, the One- sample T-test was employed. Table (13) illustrates the results of the fifth hypothesis test.

Table 13. Results of the fifth hypothesis T-test

\begin{tabular}{cccccc}
\hline Variable & T tabulated & T calculated & $\begin{array}{c}\text { Statistical } \\
\text { significance }\end{array}$ & D.F. & $\begin{array}{c}\text { Hypothesis test } \\
\text { result }\end{array}$ \\
\hline Applying bases & 1.660 & 5.308 & 0.000 & 97 & rejection \\
\hline
\end{tabular}

The test results in Table 13 show that the value of $\mathrm{T}$ calculated (5.308) is greater them that of $\mathrm{T}$ tabulated (1.660) with the significance level $(0.000)$ Hence, the null hypothesis is rejected and the alternative hypothesis is accepted. The latter hypothesis states that public industrial stock companies in Jordan do have the bases for applying social responsibility accounting. 


\section{Results}

In the light of the theoretical framework data analysis and hypothesis tests the following results:

1) Public industrial stock companies in Jordan contribute to activities related to social responsibility areas. However, these areas of social responsibility were not given the same weight. Priority was given to product quality and consumer protection, than came human resources and environment, and finally came local community:

- Product quality improvement and consumer production came first with a total mean (3.83) and standard deviation (0.64) high approval; this of course reflects the importance of a consumer from the company's view point. They are viewed as the market on which the company's survival depends. Hence, one of the company's major goals is to satisfy the customer's needs.

- Human resources development came second with a total mean (3.37) and standard deviation (0.50). This stresses the fact that companies have fair bases for salaries, promotion and incentives, and provide appropriate working conditions for workers. This contributes to workers' satisfaction and psychological stability, which, in turn, benefits both the company and the workers. However, companies do not pay enough attention to forming sport teams, educating workers' children and carrying out recreational programmers. These are considered to be extra costs from the viewpoint of these companies. This activity, in fact, enhances workers' trust and pride in their company and act as indirect promotional advertising to the company.

- Environment pollution came third with a total meal $(3,24)$ and standard deviation $(0,55)$ this was represented by the company's contribution to environmental pollution programmes, beautification and afforestation of the surrounding areas, and treatment and cycling production waste. However, there were no departments or offices responsible for pollution reduction and there was rather a scarcity of research associated with environmental pollution.

- Local community service came fourth with a total mean $(3,14)$ and standard deviation $(0,61)$. Companies showed interest in teaching university and college students, supporting educational institutions and health facilities, donating money to charities. In general, companies showed less attention to this area than other areas, the thing which may be due to the fact that these companies consider local community service part of the state's responsibility in general.

2) The availability of laws, systems and legislation is considered to be an essential factor that ensures the application of social responsibility accounting.

3) The accounting disclosure of social responsibility areas often takes the form of a descriptive report within the annual financial reports, with the help of some simple figures and proportions.

4) There is difficulty in measuring the financial data related to cost and social benefits, and this is reflected by accounting problems that can hardly be measured. This is due to various variations, some of which can be measured in terms of quantity and some can't. This has the effect of making the process of integrating social and financial information more complicated.

5) Lack of a uniform social accounting model, though there is a uniform disclosure of social activities. However, each company has its own way of disclosure. This is due to the lack of unified efforts on the part of all parties to establish a general framework for social responsibility accounting.

6) Public industrial stock companies in Jordan have requirements for applying social responsibility accounting, and the total mean which amounted to (3.02) indicates this fact and emphasizes the possibility of applying it.

\section{Recommendations}

About the results, the two researchers recommend the following:

- Designing and disclosing one accounting model for social responsibility accounting which illustrates social activities according to their importance.

- The necessity for developing the way financial lists are directed to include detailed and essential data about the industrial companies' social performance this has the effect of making the company's nature of work clearer and contributing to the reliability of these reports.

- Social activities influence the results of the company's economic activity. This must be reflected through financial lists; otherwise, these results will be misleading.

- The need of developing the university academic syllabuses in terms of teaching social responsibility accounting so that costs and social benefits can be measured. 
- $\quad$ The necessity for updating the legislation concerned with rendering and activating social services on the part of companies, so that these companies can enhance their ability to provide social services and disclose them in accounting.

- The necessity for developing the disclosure of social responsibility accounting to be a financial, quantitative one.

- The necessity of setting a special body of legal laws which aim to enhance the commitment level of applying social responsibility accounting.

- $\quad$ Organizing workshops and training courses for the industrial companies' workers about social responsibility accounting.

\section{References}

Abdul-Mutaal, M. S., \& Rifa'I, R. M. (2007). Strategic Administrations Degree of Freedom. Al-Marrykh House for Publishing.

Al-Fadl et al. (2002). Contemporary Accounting Problems (1st ed.). Dar Al-Maseerah for Publishing and Distribution.

Al-Farah \& Abdul-Razzaq, R. (2011). The Extent of the Disclosure of Social Responsibility Elements by the Industrial Companies Subsumed under Amman Exchange Stock for the Years 2007, 2008. The Jordan Journal in Business Administration, 7(2), 273-293.

Al-Hussaini, S. (2003). Auditing an Institution's Social Performance In The Light Of International and American Reviewing Criteria. Public Administration Institute, 39, 21-22.

Al-Qadi, H., \& Hamdan, M. (2001). Accounting Theory (1st ed.). Al-Dar Al-Elmiyyah Al-Dawlyyah for Publishing.

Al-Sharairy, M., \& Al-Momeni, G. (2006). Degree of The Participation of Jordan Industrial Companies in Social Activities and the Extent of Accounting Disclosure of Them. The Accounting and Administration and Insurance Magazine, 67, 75.

Al-Shirazy, A. M. (1990). Accounting Theory. Kuwait: Al-Salasel House.

Al-Zyoud, A. N. (2013). Social Responsibility of Jordan Banks, Studies. Administrative Sciences, 40(1).

Asongu, J. J. (2007). The Legitimacy of Strategic Corporate Social Responsibility as a Marketing Tool. Journal of Business and Policy, 1(1), 2-4.

Benjamin, A. (2008). Corporate Social Responsibility and Firm Characteristics in Sweden: Who and What Makes a Firm a Better Corporate Citizen? Master Thesis in Finance. Stockholm School of Economics.

Jarbou, Y. M. (2007). Degree of Applying Measurement and Disclosure in Social Responsibility Accounting To Financial Lists in Gaza Strip Companies. The Islamic University Magazine (Human Studies Services), 15, 239-281.

Khalaf, L. H. (2009). Environmental Pollution Accounting. Master Thesis. Denmark: Open Academy.

Laufer, W. (2003). Social Accountability and Corporate Green Washing. Netherland: Kluwer Academic Publishers.

Mattar, M., \& Al-Suwaity, M. (2008). Theoretical Initiation for Vocational Accounting Practices in Areas of Measurement Demonstration and Disclosure (2nd ed.). Jordan, Amman: Dar-Wa'il for Publishing and Distribution.

Mishra, S., \& Suar, D. (2010). Does Corporate Social Responsibility Influence Firm Performance of Indian Companies? Journal of Business Ethics, 95, 571-601.

Rahahleh, M., \& Shorairi, J. (2008). The Extent of Social Responsibility Accounting Application in the Qualified Industrial Zones in Jordan. International Management Review, 4(2), 5-17.

Smith, G. S. (2007). Maurice Stans View on Social Responsibility In The Accounting Profession. Accounting Historians Journal, 34(1), 147-172.

The Society of Banks in Jordan. (2011). Social Responsibility of Jordan Banks between 2009-2010. Society Pamphlet Series.

World Bank. (2005). Opportunities and Options for Governments To Promote Corporate Social Responsibility In Europe And Central Asia: Evidence From Bulgaria, Croatia And Romania. Working Paper. 


\section{Copyrights}

Copyright for this article is retained by the author(s), with first publication rights granted to the journal.

This is an open-access article distributed under the terms and conditions of the Creative Commons Attribution license (http://creativecommons.org/licenses/by/3.0/). 